\title{
Liquid-liquid phase separation in particles containing organics mixed with ammonium sulfate, ammonium bisulfate, ammonium nitrate or sodium chloride
}

\author{
Y. You, L. Renbaum-Wolff, and A. K. Bertram \\ Department of Chemistry, University of British Columbia, 2036 Main Mall, Vancouver, BC, V6T 1Z1, Canada \\ Correspondence to: A. K. Bertram (bertram@chem.ubc.ca)
}

Received: 19 July 2013 - Published in Atmos. Chem. Phys. Discuss.: 31 July 2013

Revised: 31 October 2013 - Accepted: 1 November 2013 - Published: 3 December 2013

\begin{abstract}
As the relative humidity varies from high to low values in the atmosphere, particles containing organic species and inorganic salts may undergo liquid-liquid phase separation. The majority of the laboratory work on this subject has used ammonium sulfate as the inorganic salt. In the following we studied liquid-liquid phase separation in particles containing organics mixed with the following salts: ammonium sulfate, ammonium bisulfate, ammonium nitrate and sodium chloride. In each experiment one organic was mixed with one inorganic salt and the liquid-liquid phase separation relative humidity (SRH) was determined. Since we studied 23 different organics mixed with four different salts, a total of 92 different particle types were investigated. Out of the 92 types, 49 underwent liquid-liquid phase separation. For all the inorganic salts, liquid-liquid phase separation was never observed when the oxygen-to-carbon elemental ratio $(\mathrm{O}: \mathrm{C}) \geq 0.8$ and was always observed for $\mathrm{O}: \mathrm{C}<0.5$. For $0.5 \leq \mathrm{O}: \mathrm{C}<0.8$, the results depended on the salt type. Out of the 23 organic species investigated, the SRH of 20 organics followed the trend: $\left(\mathrm{NH}_{4}\right)_{2} \mathrm{SO}_{4} \geq \mathrm{NH}_{4} \mathrm{HSO}_{4} \geq \mathrm{NaCl}$ $\geq \mathrm{NH}_{4} \mathrm{NO}_{3}$. This trend is consistent with previous salting out studies and the Hofmeister series. Based on the range of $\mathrm{O}: \mathrm{C}$ values found in the atmosphere and the current results, liquid-liquid phase separation is likely a frequent occurrence in both marine and non-marine environments.
\end{abstract}

\section{Introduction}

A large fraction of atmospheric particles contain both organic material and inorganic salts (Murphy et al., 1998, 2006; Zhang et al., 2007; Pratt and Prather, 2010). The number of possible inorganic salts is relatively small with ammonium sulfate, ammonium bisulfate, ammonium nitrate and sodium chloride thought to be important (Finlayson-Pitts and Pitts, 2000; Seinfeld and Pandis, 2006). In contrast, the number of organic species can be in the 100s to 1000s (Hamilton et al., 2004; Goldstein and Galbally, 2007) while only around $10 \%$ of these organic species have been identified at the molecular level (Hallquist et al., 2009).

As the relative humidity cycles in the atmosphere, particles containing a mixture of organic material and inorganic salts can undergo a range of phase transitions including deliquescence, efflorescence and liquid-liquid phase separation (Martin, 2000; Clegg et al., 2001; Brooks et al., 2002; Pankow, 2003; Braban and Abbatt, 2004; Erdakos and Pankow, 2004; Marcolli and Krieger, 2006; Erdakos et al., 2006a; Chang and Pankow, 2006; Anttila et al., 2007; Buajarern et al., 2007a; Ciobanu et al., 2009; Zuend et al., 2010; Bertram et al., 2011; Reid et al., 2011; Song et al., 2012a). Knowledge of these phase transitions is required for predicting the roles of aerosol particles in air quality and climate. For example partitioning of organic molecules between the gas and particle can depend on the phase of atmospheric particles (Chang and Pankow, 2006; Zuend et al., 2010). Particle phase can also influence the reactive uptake of gas-phase species, the optical properties of particles, and ice nucleation properties of particles, all of which can influence air quality or climate (Martin, 2000; Adams et al., 2001; Zuberi et al., 
2002; Folkers et al., 2003; Thornton et al., 2003; Martin et al., 2004; Abbatt et al., 2006; Anttila et al., 2006; Forster et al., 2007; Riemer et al., 2009; Escoreia et al., 2010; Wise et al., 2010; You et al., 2012).

Many studies on phase transitions of mixed organicinorganic salt particles of atmospheric relevance have focused on deliquescence and efflorescence (see for example Brooks et al., 2002, 2003; Choi and Chan, 2002; Chan and Chan, 2003; Wise et al., 2003; Braban and Abbatt, 2004; Pant et al., 2004; Parsons et al., 2004a, 2006; Badger et al., 2006; Marcolli and Krieger, 2006; Salcedo, 2006; Ling and Chan, 2008; Treuel et al., 2009; Bertram et al., 2011; Smith et al., 2012). These studies have shown that when liquidliquid phase separation does not occur, the addition of organics to inorganic salts lowers the deliquescence and efflorescence relative humidities of the salts. As a result, some atmospheric particles may remain in a single homogeneous liquid state for the full range of relative humidities found in the atmosphere.

More recent studies on phase transitions of mixed organicinorganic salt particles of atmospheric relevance have focused on liquid-liquid phase separations (Clegg et al., 2001; Pankow, 2003; Marcolli and Krieger, 2006; Chang and Pankow, 2006; Erdakos et al., 2006b; Anttila et al., 2007; Buajarern et al., 2007a, b; Ciobanu et al., 2009; Kwamena et al., 2010; Zuend et al., 2010; Prisle et al., 2010; Bertram et al., 2011; Smith et al., 2011, 2013; Reid et al., 2011; Song et al., 2012a, b; You et al., 2012). The majority of the laboratory work on this subject has used ammonium sulfate as the inorganic salt.

In the following we studied liquid-liquid phase separation in particles containing organics mixed with the following salts: ammonium sulfate, ammonium bisulfate, ammonium nitrate and sodium chloride. In each experiment one organic was mixed with one inorganic salt and the liquid-liquid phase separation relative humidity (SRH) was determined. Since we studied 23 different organics mixed with four different salts, a total of 92 different particle types were investigated. These studies provide insight into the effect of salt type on liquid-liquid phase separation in atmospheric particles.

\section{Experimental}

Shown in Table 1 is the list of the organics studied. The organics investigated had a wide range of oxygen-to-carbon elemental ratios $(\mathrm{O}: \mathrm{C})$ (from 0.29 to 1.33), covering the most of the range of $\mathrm{O}: \mathrm{C}$ often observed in atmospheric particles (approximately 0.1 to 1.0) (Aiken et al., 2008; DeCarlo et al., 2008; Chen et al., 2009; Jimenez et al., 2009; Hawkins et al., 2010; Heald et al., 2010; $\mathrm{Ng}$ et al., 2010; Takahama et al., 2011). The organic species studied herein also included several functional groups observed in atmospheric samples (e.g. carboxylic acids, alcohols, esters, ethers and aromat- ics) (Rogge et al., 1993; Saxena and Hildemann, 1996; Finlayson-Pitts and Pitts, 1997; Decesari et al., 2006; Seinfeld and Pandis, 2006; Day et al., 2009; Gilardoni et al., 2009; Hallquist et al., 2009; Liu et al., 2009; Russell et al., 2009, 2011; Fu et al., 2011; Takahama et al., 2011).

All organic compounds studied herein were purchased from Sigma-Aldrich with purities $\geq 98 \%$, with the exception of suberic acid monomethyl ester and 1,2,6-hexanetriol, which were purchased from Sigma-Aldrich with a purity of $97 \%$, and glycerol, which was obtained from Thermo Fisher Scientific with a purity of $99.9 \%$. All organics were used without further purification.

The organic-to-inorganic mass ratio (OIR) in the particle was fixed at $2.0 \pm 0.1$ for most of the experiments. This value is in the range of OIR values observed in many field studies (Zhang et al., 2007; Jimenez et al., 2009). In addition, previous research using solutions or particles containing organics mixed with ammonium sulfate suggest that SRH often is not dependent on the OIR for a wide range of OIR values (Ciobanu et al., 2009; Bertram et al., 2011; Song et al., 2012a, b). As an example, Bertram et al. (2011) investigated the effect of OIR on SRH in eleven different types of particles containing organics and ammonium sulfate. For eight out of the eleven systems investigated, the SRH varied by less than $6 \%$ for OIR values ranging from 0.1 to 10 . As another example, Song et al. (2012b) measured SRH in particles containing ammonium sulfate and up to ten organics with OIR ranging from 0.17 to 2 . The results of that study showed that for nine out of the fourteen systems that underwent liquidliquid phase separation, the SRH varied by less than $15 \%$ as the OIR varied from 0.17 to 2 .

Particles were generated by nebulizing (Meinhard) a solution of one organic compound and one salt, prepared in high-purity water (Millipore, $18.2 \mathrm{M} \Omega \mathrm{cm}$ ) or in a mixture of water and methanol if the water solubility of the organic compound was less than 1 weight/weight $\%$. The particle stream from the nebulizer was directed at a hydrophobic slide surface. As the droplets impacted on the slide surface, they coagulated into supermicron droplets. The water or the water/methanol mixture was then evaporated to generate organic-inorganic salt particles with lateral dimensions ranging from 10 to $35 \mu \mathrm{m}$.

The only two organic species that had a solubility of less than $1 \%$ (weight/weight) in water were liquid diethyl sebacate and liquid suberic acid monomethyl ester. Based on this solubility information, liquid-liquid phase separation is expected for these species even without the presence of a salt at roughly $\geq 99 \% \mathrm{RH}$.

The glass slide was mounted to a temperature and relative humidity controlled flow cell, which was coupled to an optical reflectance microscope (Zeiss Axiotech; $50 \times$ objective) (Koop et al., 2000; Parsons et al., 2004b; Pant et al., 2006; Bodsworth et al., 2010). The temperature of the cell was held constant at $290 \pm 1 \mathrm{~K}$ in all the experiments described here. To control the relative humidity in the flow cell, 
a combination of dry and humidified nitrogen gas was continuously passed through the cell. The total flow rate was approximately $1.5 \mathrm{~L} \mathrm{~min}^{-1}$. The relative humidity of the gas was determined using a chilled mirror hygrometer (General Eastern), which was calibrated by measuring the deliquescence relative humidity of ammonium sulfate particles.

At the beginning of an experiment, the RH in the flow cell was first set to nearly $95 \%$ and particles were allowed to equilibrate for about $15 \mathrm{~min}$. The RH was then ramped down at a rate of $0.4-0.6 \% \mathrm{~min}^{-1}$, and images of the particles were captured approximately every $10 \mathrm{~s}$ until one of the following conditions occurred: liquid-liquid phase separation was observed, the particles effloresced, or an RH of $\leq 0.5 \%$ was reached. For each different type of organic-inorganic salt particle, experiments were repeated at least three times. Roughly 5 particles were monitored in each experiment. For particles containing diethyl sebacate or suberic acid monomethyl ester, experiments started at $\mathrm{RH}=100 \pm 2.5 \%$ since the $\mathrm{RH}$ of liquid-liquid phase separation was greater than $95 \%$.

While the RH was decreased, liquid-liquid phase separation could be identified from the recorded images. To illustrate this point we have included images and movies of particles containing 2-methylglutaric acid mixed with different inorganic salts as the relative humidity was decreased (Fig. 1 $\mathrm{a}-\mathrm{d}$ and Movies S1-S4). The images and movies show that all particle types containing 2-methylglutaric acid at an OIR of $2.0 \pm 0.1$ underwent liquid-liquid phase separation.

\section{Results and discussion}

\subsection{Effect of $\mathrm{H}$ : $\mathrm{C}$ (hydrogen-to-carbon elemental ratio), $O: C$, and inorganic salt type on liquid-liquid phase separation}

Listed in Table 2 are the measured SRH values for the different particle types investigated. Out of 92 particle types, 49 underwent liquid-liquid phase separation between $100 \%$ and $\leq 0.5 \%$ RH. These results are summarized in Fig. 2, which shows the dependence of observed liquid-liquid phase separation on the $\mathrm{O}: \mathrm{C}$ and $\mathrm{H}: \mathrm{C}$ (hydrogen-to-carbon elemental ratios) of the organic components of the particles. No trend with $\mathrm{H}: \mathrm{C}$ is apparent for any of the salts studied. However, a trend with $\mathrm{O}: \mathrm{C}$ is apparent: for all salts, liquid-liquid phase separation was never observed for $\mathrm{O}: \mathrm{C} \geq 0.8$ and was always observed for $\mathrm{O}: \mathrm{C}<0.5$. For $0.5 \leq \mathrm{O}: \mathrm{C}<0.8$, the results depended on the salt type. For ammonium sulfate, phase separation was always observed for $0.5 \leq \mathrm{O}: \mathrm{C}<0.57$ and phase separation was frequently observed for $0.57 \leq \mathrm{O}: \mathrm{C}$ $<0.8$. For the other three salts, phase separation was frequently observed for $0.5 \leq \mathrm{O}: \mathrm{C}<0.8$.

To further investigate the effect of $\mathrm{O}: \mathrm{C}$ on liquid-liquid phase separation, the measured SRH values are plotted as a function of $\mathrm{O}: \mathrm{C}$ in Fig. 3. The solid curves in the figure are fits to all the data using a Sigmoidal-Boltzmann function.

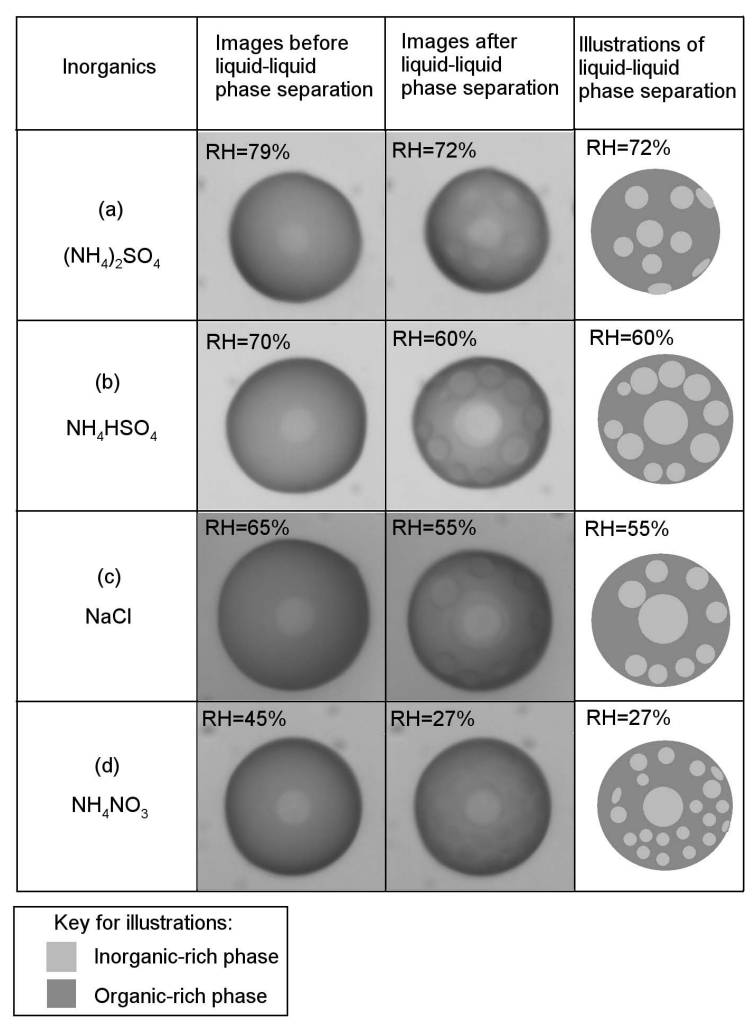

Fig. 1. Optical images and illustrations of particles containing 2methylglutaric acid and one of the inorganic salts with OIR $=2.0 \pm$ 0.1 . Shown in the images and illustrations are the relative humidities at which the images were recorded. The inorganic salts studied were ammonium sulfate in row (a), ammonium bisulfate in row (b), sodium cholride in row (c), and ammonium nitrate in row (d). The diameter of the particles shown ranged from 28 to $34 \mu \mathrm{m}$.

Following Song et al. (2012b), the Sigmoidal-Boltzmann function was chosen to avoid physically unrealistic values at both low and high $\mathrm{O}: \mathrm{C}$ values. Many of the systems in which phase separation was observed (i.e. SRH-values $>0 \%$ ) lie above the fit line since the curve was fit to both zero and non-zero SRH values. Alternatively we could have fit only the non-zero SRH values, but this would give extra weight to cases where phase separation was observed. The results of the fits are given in Table 3. The fit to the ammonium sulfate SRH-data is qualitatively consistent with fits previously reported in the literature for ammonium sulfate SRHdata (Bertram et al., 2011; Song et al., 2012b).

Although the results for each inorganic salt do not fall perfectly on the fit curves in Fig. 3, a correlation between O:C and SRH is observed. This suggests that $\mathrm{O}: \mathrm{C}$ is a useful parameter for estimating, to a first approximation, the relative humidity for liquid-liquid phase separation, as shown previously for particles containing organics with ammonium sulfate (Bertram et al., 2011; Song et al., 2012a, b). For highaccuracy predictions, additional information such as the organic functional groups is required (Song et al., 2012b). 
Table 1. Summary of different organics used in the liquid-liquid phase separation experiments.

\begin{tabular}{|c|c|c|c|c|c|}
\hline Compounds & Formula & Molecular weight & $\mathrm{O}: \mathrm{C}$ & $\mathrm{H}: \mathrm{C}$ & Functional group(s) \\
\hline Diethyl sebacate & $\mathrm{C}_{14} \mathrm{H}_{26} \mathrm{O}_{4}$ & 258.4 & 0.29 & 1.86 & ester \\
\hline 2,5-hexanediol & $\mathrm{C}_{6} \mathrm{H}_{14} \mathrm{O}_{2}$ & 118.2 & 0.33 & 2.33 & alcohol \\
\hline Poly (propylene glycol) & $\mathrm{C}_{3 n} \mathrm{H}_{6 n+2} \mathrm{O}_{n+1}$ & 425 & 0.38 & 2.10 & alcohol, ether \\
\hline Poly (ethylene glycol) diacrylate & $\mathrm{C}_{2 n+6} \mathrm{H}_{4 n+6} \mathrm{O}_{n+3}$ & 575 & 0.50 & 1.77 & ester, ether, C-C double bond \\
\hline 1,2,6-hexanetriol & $\mathrm{C}_{6} \mathrm{H}_{14} \mathrm{O}_{3}$ & 134.2 & 0.50 & 2.33 & alcohol \\
\hline$\alpha, 4$-dihydroxy-3-methoxybenzeneacetic acid & $\mathrm{C}_{9} \mathrm{H}_{10} \mathrm{O}_{5}$ & 198.2 & 0.56 & 1.11 & alcohol, aromatic, carboxylic acid, ether \\
\hline 3,3-dimethylglutaric acid & $\mathrm{C}_{7} \mathrm{H}_{12} \mathrm{O}_{4}$ & 160.2 & 0.57 & 1.71 & carboxylic acid \\
\hline Poly (ethylene glycol) 300 & $\mathrm{C}_{2 n} \mathrm{H}_{4 n+2} \mathrm{O}_{n+1}$ & 300 & 0.58 & 2.17 & alcohol, ether \\
\hline Poly (ethylene glycol) 200 & $\mathrm{C}_{2 n} \mathrm{H}_{4 n+2} \mathrm{O}_{n+1}$ & 200 & 0.63 & 2.25 & alcohol, ether \\
\hline Poly (ethylene glycol) bis (carboxymethyl) ether & $\mathrm{C}_{2 n+4} \mathrm{H}_{4 n+6} \mathrm{O}_{n}+5$ & 600 & 0.63 & 1.92 & ester, ether, carboxylic acid \\
\hline 2,2-dimethylsuccinic acid & $\mathrm{C}_{6} \mathrm{H}_{10} \mathrm{O}_{4}$ & 146.2 & 0.67 & 1.67 & carboxylic acid \\
\hline 2-methylglutaric acid & $\mathrm{C}_{6} \mathrm{H}_{10} \mathrm{O}_{4}$ & 146.1 & 0.67 & 1.67 & carboxylic acid \\
\hline Glycerol & $\mathrm{C}_{3} \mathrm{H}_{8} \mathrm{O}_{3}$ & 92.1 & 1.00 & 2.67 & alcohol \\
\hline Citric acid & $\mathrm{C}_{6} \mathrm{H}_{8} \mathrm{O}_{7}$ & 192.1 & 1.17 & 1.33 & alcohol, carboxylic acid \\
\hline Malic acid & $\mathrm{C}_{4} \mathrm{H}_{6} \mathrm{O}_{5}$ & 134.9 & 1.25 & 1.5 & alcohol, carboxylic acid \\
\hline Malonic acid & $\mathrm{C}_{3} \mathrm{H}_{4} \mathrm{O}_{4}$ & 104.1 & 1.33 & 1.33 & carboxylic acid \\
\hline
\end{tabular}

Table 2. Summary of SRH results for an organic-to-inorganic mass ratio (OIR) of $2.0 \pm 0.1$. Uncertainties represent $2 \sigma$ of multiple SRH measurements and the uncertainty from the calibration.

\begin{tabular}{|c|c|c|c|c|c|c|c|c|}
\hline \multirow[t]{2}{*}{ Organics } & \multicolumn{2}{|c|}{$\left(\mathrm{NH}_{4}\right)_{2} \mathrm{SO}_{4}$} & \multicolumn{2}{|r|}{$\mathrm{NH}_{4} \mathrm{HSO}_{4}$} & \multicolumn{2}{|r|}{$\mathrm{NaCl}$} & \multicolumn{2}{|c|}{$\mathrm{NH}_{4} \mathrm{NO}_{3}$} \\
\hline & OIR & $\mathrm{SRH}(\%)$ & OIR & $\mathrm{SRH}(\%)$ & OIR & SRH $(\%)$ & OIR & SRH $(\%)$ \\
\hline Diethyl sebacate & 2.0 & $100.0 \pm 2.5$ & 2.0 & $100.0 \pm 2.5$ & 2.0 & $100.0 \pm 2.5$ & 2.0 & $100.0 \pm 2.5$ \\
\hline 2,5-hexanediol & 2.0 & $88.8 \pm 3.7$ & 2.1 & $81.0 \pm 3.7$ & 2.0 & $72.4 \pm 2.6$ & 2.1 & $63.9 \pm 4.1$ \\
\hline Poly (propylene glycol) & 2.0 & $94.1 \pm 3.2$ & 2.0 & $90.3 \pm 3.1$ & 2.0 & $89.6 \pm 2.7$ & 2.0 & $77.6 \pm 2.5$ \\
\hline Suberic acid monomethyl ester & 2.0 & $100.0 \pm 2.5$ & 2.0 & $100.0 \pm 2.5$ & 1.9 & $100.0 \pm 2.5$ & 2.1 & $100.0 \pm 2.5$ \\
\hline Poly (ethylene glycol) diacrylate & 2.0 & $94.7 \pm 2.5$ & 2.0 & $91.0 \pm 2.9$ & 2.0 & $87.0 \pm 2.7$ & 2.0 & $69.4 \pm 4.4$ \\
\hline 1,2,6-hexanetriol & 2.1 & $76.7 \pm 2.5$ & 2.0 & Not observed $*$ & 2.0 & Not observed & 2.1 & Not observed \\
\hline$\alpha, 4$-dihydroxy-3-methoxybenzeneacetic acid & 2.0 & $72.6 \pm 2.6$ & 2.0 & $38.2 \pm 2.7$ & 1.9 & $63.1 \pm 2.9$ & 1.9 & Not observed \\
\hline 2,5-dihydroxybenzoic acid & 2.0 & Not observed & 1.9 & Not observed & 2.0 & $65.5 \pm 3.1$ & 2.0 & Not observed \\
\hline Diethylmalonic acid & 2.0 & $89.2 \pm 3.0$ & 2.0 & $88.1 \pm 2.6$ & 1.9 & $87.4 \pm 3.0$ & 2.1 & $74.1 \pm 3.7$ \\
\hline 3,3-dimethylglutaric acid & 2.0 & $89.1 \pm 3.4$ & 2.0 & $88.7 \pm 5.0$ & 2.1 & $85.6 \pm 2.6$ & 2.0 & $60.5 \pm 2.6$ \\
\hline Poly (ethylene glycol) 300 & 2.0 & $86.7 \pm 2.8$ & 1.9 & Not observed & 2.0 & Not observed & 2.0 & Not observed \\
\hline Poly (ethylene glycol) 200 & 2.0 & $79.8 \pm 4.1$ & 2.0 & Not observed & 2.0 & Not observed & 2.0 & Not observed \\
\hline Poly (ethylene glycol) bis (carboxymethyl) ether & 2.0 & $92.0 \pm 2.7$ & 2.0 & $53.6 \pm 3.1$ & 2.0 & $49.0 \pm 2.6$ & 2.0 & Not observed \\
\hline 2,2-dimethylsuccinic acid & 2.0 & Not observed & 2.0 & $61.4 \pm 2.5$ & 2.1 & $58.9 \pm 2.6$ & 1.9 & $40.0 \pm 3.2$ \\
\hline 2-methylglutaric acid & 2.0 & $75.3 \pm 2.8$ & 2.0 & $64.5 \pm 4.4$ & 2.1 & $60.1 \pm 2.5$ & 2.0 & $34.5 \pm 3.0$ \\
\hline Diethyl-L-tartrate & 2.1 & $90.2 \pm 3.0$ & 2.1 & $65.2 \pm 4.1$ & 2.0 & $52.5 \pm 2.5$ & 2.0 & $28.7 \pm 5.6$ \\
\hline Glutaric acid & 2.0 & Not observed & 1.9 & Not observed & 2.0 & Not observed & 2.0 & Not observed \\
\hline Levoglucosan & 2.0 & Not observed & 1.9 & Not observed & 1.9 & Not observed & 1.9 & Not observed \\
\hline Maleic acid & 2.0 & Not observed & 2.0 & Not observed & 2.0 & Not observed & 1.9 & Not observed \\
\hline Glycerol & 2.0 & Not observed & 1.9 & Not observed & 2.0 & Not observed & 2.1 & Not observed \\
\hline Citric acid & 2.0 & Not observed & 2.0 & Not observed & 1.9 & Not observed & 1.9 & Not observed \\
\hline Malic acid & 2.1 & Not observed & 1.9 & Not observed & 1.9 & Not observed & 1.9 & Not observed \\
\hline Malonic acid & 2.0 & Not observed & 2.0 & Not observed & 2.0 & Not observed & 2.0 & Not observed \\
\hline
\end{tabular}

than this value, efflorescence of the salts occurred. 


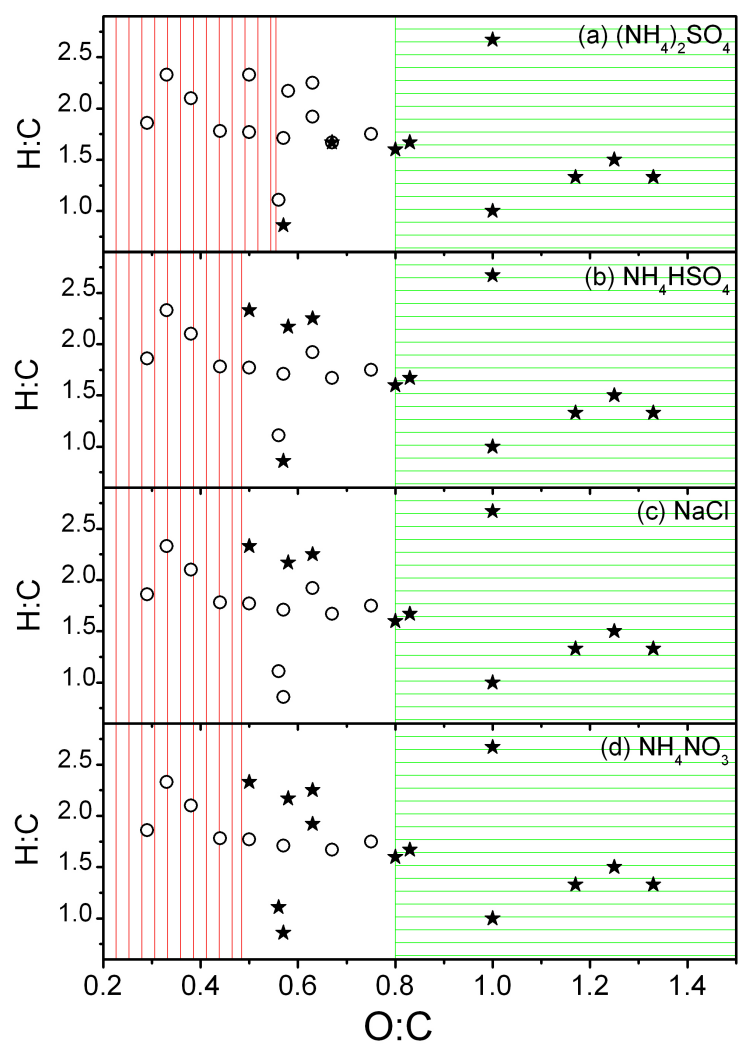

Fig. 2. Van Krevelen Diagram for the different mixed organicinorganic salt particles (OIR $=2.0 \pm 0.1)$ studied: (a) organicammonium sulfate particles, (b) organic-ammonium bisulfate particles, (c) organic-sodium chloride particles and (d) organicammonium nitrate particles. Open circles indicate that liquid-liquid phase separation was observed, while stars indicate that liquidliquid phase separation was not observed. The vertical hatched regions correspond to the $\mathrm{H}: \mathrm{C}$ and $\mathrm{O}: \mathrm{C}$ conditions when liquidliquid phase separation was always observed and the horizontal hatched regions correspond to the $\mathrm{H}: \mathrm{C}$ and $\mathrm{O}: \mathrm{C}$ conditions when liquid-liquid phase separation was never observed.

Marcolli and Krieger recently measured SRH in bulk solutions containing one organic mixed with ammonium nitrate or sodium chloride (Marcolli and Krieger, 2006). Organics studied were 1,2-hexanediol $(\mathrm{O}: \mathrm{C}=0.33)$, 1,4-butanediol $(\mathrm{O}: \mathrm{C}=0.5)$, polyethylene glycol $(\mathrm{MW}=400$ and $\mathrm{O}: \mathrm{C}$ $=0.56)$ and glycerol $(\mathrm{O}: \mathrm{C}=1)$. Only one of these organics, glycerol, was investigated in the current study (see Table 1). The SRH data from Marcolli and Krieger (2006) is included in Fig. 3 as a function of $\mathrm{O}: \mathrm{C}$ (red triangles), together with the results of this study. The overlap between the current data and the data from Marcolli and Krieger (2006) suggest good agreement between the particle studies and the bulk studies.

SRH results shown in Fig. 3 do not vary drastically with the types of inorganic salt. However, out of the 23 organics investigated, the SRH of 20 organics followed the SRH trend: $\left(\mathrm{NH}_{4}\right)_{2} \mathrm{SO}_{4} \geq \mathrm{NH}_{4} \mathrm{HSO}_{4} \geq \mathrm{NaCl} \geq \mathrm{NH}_{4} \mathrm{NO}_{3}$ (see Fig. 4a). In other words, the SRH-value measured with $\left(\mathrm{NH}_{4}\right)_{2} \mathrm{SO}_{4}$
Table 3. Parameterizations of SRH results as a function of the oxygen-to-carbon elemental ratio $(\mathrm{O}: \mathrm{C})$ of the organic material.

\begin{tabular}{ll}
\hline Inorganic salt & Parameterizations of SRH \\
\hline$\left(\mathrm{NH}_{4}\right)_{2} \mathrm{SO}_{4}$ & $\mathrm{SRH} \%=\frac{100}{1+\exp \frac{(\mathrm{O}: \mathrm{C})-0.68}{0.10}} \times 100 \%$ \\
$\mathrm{NH}_{4} \mathrm{HSO}_{4}$ & $\mathrm{SRH} \%=\frac{100}{1+\exp \frac{(\mathrm{O}: \mathrm{C})-0.57}{0.14}} \times 100 \%$ \\
$\mathrm{NaCl}$ & $\mathrm{SRH} \%=\frac{100}{1+\exp \frac{(\mathrm{O}: \mathrm{C})-0.60}{0.14}} \times 100 \%$ \\
$\mathrm{NH}_{4} \mathrm{NO}_{3}$ & $\mathrm{SRH} \%=\frac{100}{1+\exp \frac{(\mathrm{O}: \mathrm{C})-0.49}{0.09}} \times 100 \%$
\end{tabular}

was greater than or equal to the SRH-value measured with $\mathrm{NH}_{4} \mathrm{HSO}_{4}$, and so on. Early in the last century, Randall and Failey showed the following trends for the salting out efficiencies of ions relevant to our work: $\mathrm{Na}^{+}>\mathrm{NH}_{4}^{+}>\mathrm{H}^{+}$ and $\mathrm{SO}_{4}^{2-}>\mathrm{Cl}^{-}>\mathrm{NO}_{3}^{-}$(Randall and Failey, 1927). In addition, the Hofmeister series, which consists of a ranking of cations and anions in terms of their ability to salt out proteins follows the same trend (i.e. $\mathrm{Na}^{+}>\mathrm{NH}_{4}^{+}$and $\mathrm{SO}_{4}^{2-}>\mathrm{Cl}^{-}$ $>\mathrm{NO}_{3}^{-}$) (Hofmeister, 1887, 1888; Kunz et al., 2004). These trends allow one to compare the salting out efficiency (or SRH) of two salts if they have a common cation or anion. Based on these early salting out studies, we would expect $\left(\mathrm{NH}_{4}\right)_{2} \mathrm{SO}_{4}$ to have a greater salting out efficiency (or higher $\mathrm{SRH}$ ) compared to $\mathrm{NH}_{4} \mathrm{HSO}_{4}$ since the salting out efficiency follows the trend $\mathrm{NH}_{4}^{+}>\mathrm{H}^{+}$. In addition, we would expect $\left(\mathrm{NH}_{4}\right)_{2} \mathrm{SO}_{4}$ to have a greater salting out efficiency (or higher $\mathrm{SRH}$ ) than $\mathrm{NH}_{4} \mathrm{NO}_{3}$, since the salting out efficiency follows the trend $\mathrm{SO}_{4}^{2-}>\mathrm{NO}_{3}^{-}$. These expectations are consistent with the trends observed for 20 out of the 23 organics investigated (Fig. 4a).

Three organics (2,5-dihydroxybenzonic acid, $\alpha$, 4-dihydroxy-3-methoxybenzeneaceticacid, and 2,2dimethylsuccinic acid) were inconsistent with the $\mathrm{SRH}$ trend $\left(\mathrm{NH}_{4}\right)_{2} \mathrm{SO}_{4} \geq \mathrm{NH}_{4} \mathrm{HSO}_{4} \geq \mathrm{NaCl} \geq \mathrm{NH}_{4} \mathrm{NO}_{3}$ when using an OIR of $2.0 \pm 0.1$. The results from these organics are illustrated in Fig. 4b. Interestingly, Bertram et al. (2011) also measured SRH values for these organics mixed with ammonium sulfate and found that the SRH values for these organics varied by more than $6 \%$ with the OIR of the particles. In fact, the SRH of these three organics were the only ones observed to vary by more than $6 \%$ with OIR out of the 13 organics studied by Bertram et al. (2011). To investigate this further we have measured SRH for these three organics mixed with the different salts using OIR values lower than $2.0 \pm 0.1$. The results from these measurements as well as the results from Bertram et al. (2011) are shown in Fig. 5 and are summarized in Table 4. 


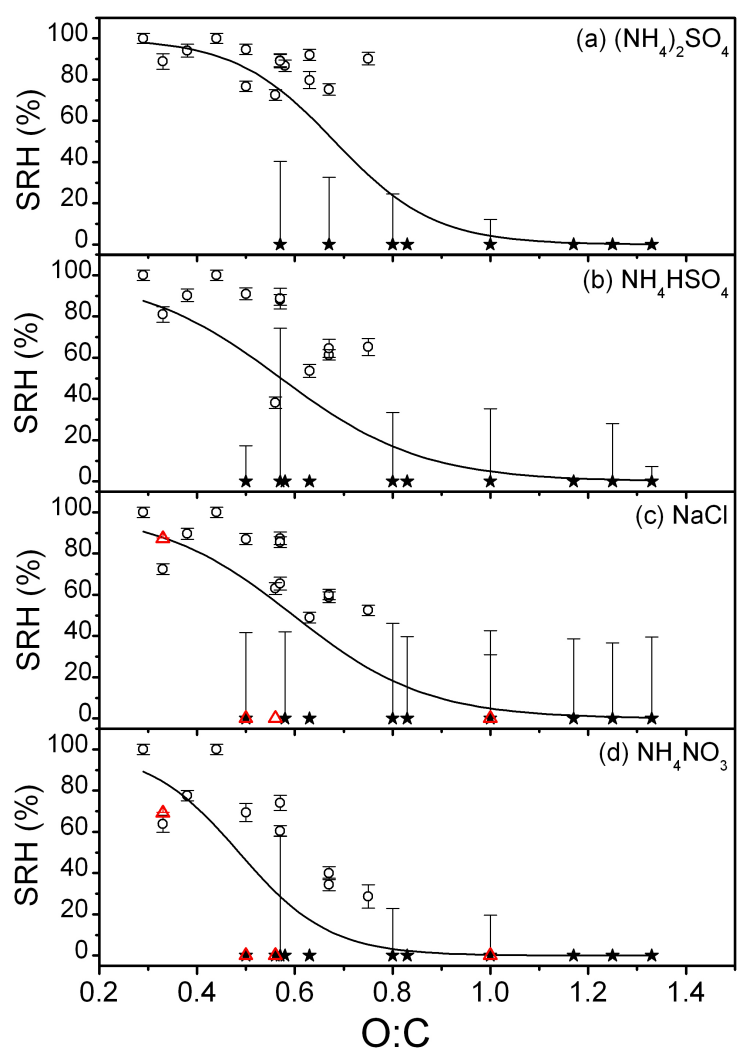

Fig. 3. Summary of SRH results $(\mathrm{OIR}=2.0 \pm 0.1)$ as a function of oxygen-to-carbon elemental ratio $(\mathrm{O}: \mathrm{C})$ : (a) organic-ammonium sulfate particles, (b) organic-ammonium bisulfate particles, (c) organic-sodium chloride particles and (d) organic-ammonium nitrate particles. Circles represent the relative humidity at which separation occurred. Error bars associated with the circles represent $2 \sigma$ of multiple SRH measurements and the uncertainty from the calibration. Stars indicate that liquid-liquid phase separation was not observed. The error bars corresponding to the stars indicate that liquid-liquid phase separation could potentially occur within the range indicated by the error bars, but could not be detected due to the occurrence of efflorescence in the particles. The curves in the panels are Sigmoidal-Boltzmann fits to the data. Red triangles represent the results of liquid-liquid phase separation in bulk solution from Marcolli and Krieger 2006).

Figure 5a shows that for OIR $\leq 0.5$, SRH of 2,2dimethylsuccinic acid followed the trend of $\left(\mathrm{NH}_{4}\right)_{2} \mathrm{SO}_{4} \geq$ $\mathrm{NH}_{4} \mathrm{HSO}_{4} \geq \mathrm{NaCl} \geq \mathrm{NH}_{4} \mathrm{NO}_{3}$, consistent with the 20 organics shown in Fig. 4a. Hence the anomaly at OIR $=2$ for 2,2-dimethylsuccinic acid is absent at an OIR of $\leq 0.5$. In other words, the trend for 2,2-dimethylsuccinic acid is consistent with the other 20 organics as long as the OIR is in a range where particles undergo liquid-liquid phase separation.

Figure $5 \mathrm{~b}$ and $5 \mathrm{c}$ show that $\alpha$,4-dihydroxy-3methoxybenzeneacetic acid and 2,5-dihydroxybenzonic acid do not follow the trend of $\left(\mathrm{NH}_{4}\right)_{2} \mathrm{SO}_{4} \geq \mathrm{NH}_{4} \mathrm{HSO}_{4} \geq$ $\mathrm{NaCl} \geq \mathrm{NH}_{4} \mathrm{NO}_{3}$ regardless of the OIR studied. Note

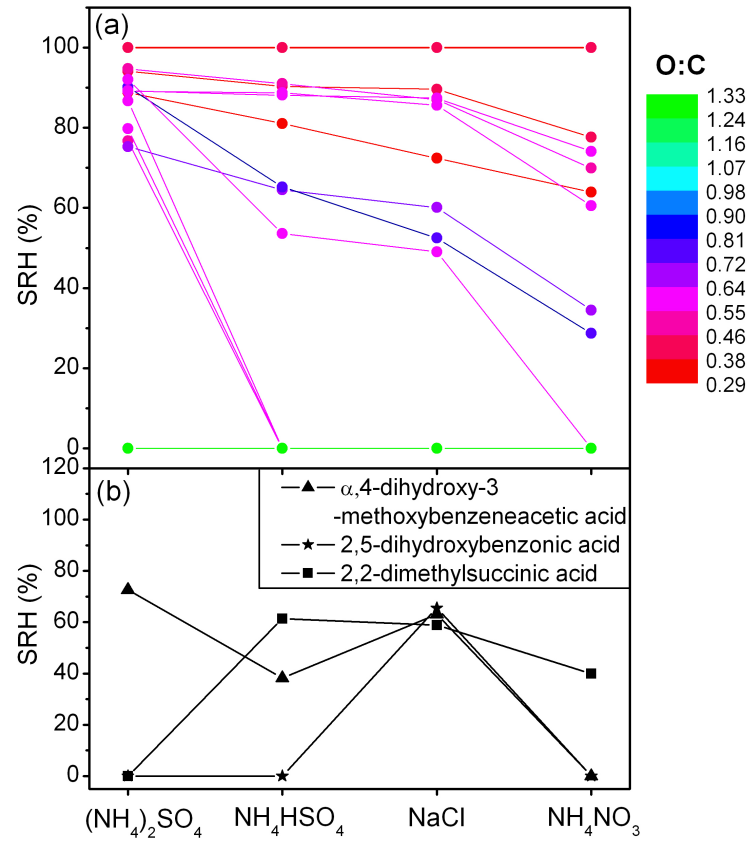

Fig. 4. Summary of trends of SRH of particles (OIR=2.0 \pm 0.1$)$ as a function of inorganic salt type: (a) the SRH of the organics $(20$ in total) that followed the trend $\left(\mathrm{NH}_{4}\right)_{2} \mathrm{SO}_{4} \geq \mathrm{NH}_{4} \mathrm{HSO}_{4} \geq \mathrm{NaCl}$ $\geq \mathrm{NH}_{4} \mathrm{NO}_{3}$ and (b) the $\mathrm{SRH}$ for 2,5-dihydroxybenzonic acid, $\alpha, 4$ dihydroxy-3-methoxybenzeneacetic acid, and 2,2-dimethylsuccinic acid. In panel a, colors represent the $\mathrm{O}: \mathrm{C}$ of individual organics. The organics shown in panel $\mathrm{b}$ didn't follow the trend $\left(\mathrm{NH}_{4}\right)_{2} \mathrm{SO}_{4} \geq \mathrm{NH}_{4} \mathrm{HSO}_{4} \geq \mathrm{NaCl} \geq \mathrm{NH}_{4} \mathrm{NO}_{3}$. Uncertainties in the $\mathrm{SRH}$ measurements have been left off for clarity.

out of all organics studied, these two organics are the only two organics which contained aromatic functional groups. One possible reason for the differences in trends of SRH observed for these organics may be due to strong cation $-\pi$ interactions (Kumpf and Dougherty, 1993; Ma and Dougherty, 1997; Song et al., 2012b). Previous work by Song et al. has suggested that cation- $\pi$ interactions may decrease the salting out effect of the ammonium cations, thereby influencing SRH values in particles containing ammonium salts and aromatic compounds (Song et al., 2012b).

SRH was only investigated as a function of OIR for three organics (2,5-dihydroxybenzonic acid, $\alpha, 4$-dihydroxy3-methoxybenzeneacetic acid, and 2,2-dimethylsuccinic acid). For the organics that were only investigated at $\mathrm{OIR}=2.0 \pm 0.1$, we don't expect that SRH will be a strong function of OIR in most cases, based on previous studies with organics and ammonium sulfate (see Experimental Section). However, experiments are needed to confirm this expectation.

Recent work has shown that chloride anions may react with organic acids in the particle phase to form organic salts (Laskin et al., 2012). This type of reaction could potentially 


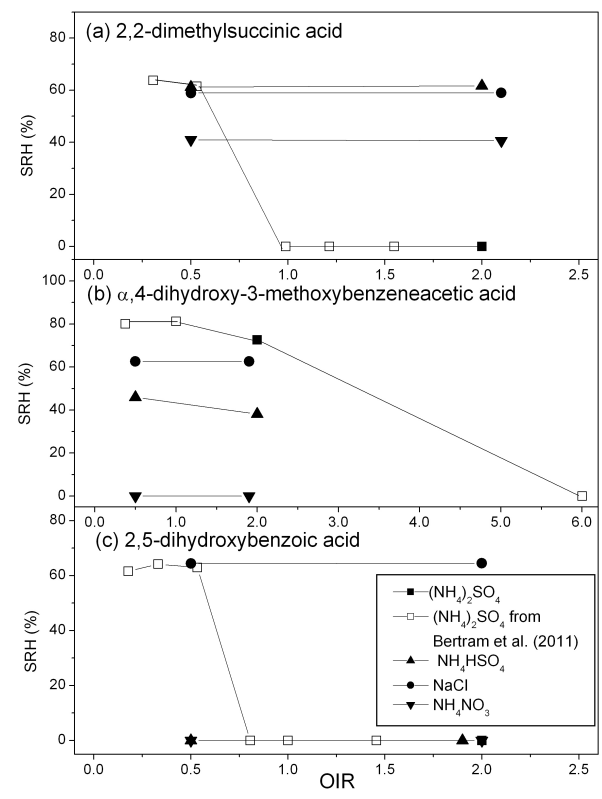

Fig. 5. Summary of SRH results as a function of OIR for the following types of particles: (a) 2,2-dimethylsuccinic acid and inorganic salts, (b) $\alpha$,4-dihydroxy-3-methoxybenzeneacetic acid and inorganic salts, and (c) 2,5-dihydroxybenzonic acid and inorganic salts. Closed symbols represent results from the current study, while open squares represent results from previous studies by Bertram et al. (2011). Uncertainties in the SRH measurements have been left off for clarity.

occur in our studies. However, if such reactions are occurring in our studies, they don't appear to drastically affect the occurrence of liquid-liquid phase separation.

\subsection{Atmospheric implications}

A large fraction of submicron particles in the atmosphere contain organics mixed with some combination of ammonium $\left(\mathrm{NH}_{4}^{+}\right)$, protons $\left(\mathrm{H}^{+}\right)$, sulfate $\left(\mathrm{SO}_{4}^{2-}\right)$ and nitrate $\left(\mathrm{NO}_{3}^{-}\right)$(Adams et al., 1999; Lee et al., 2003; Martin et al., 2004; Tolocka et al., 2005; Murphy et al., 2006; Seinfeld and Pandis, 2006; Zhang et al., 2007; Pratt and Prather, 2010). As a result the inorganic salts ammonium sulfate, ammonium bisulfate and ammonium nitrate are thought to be important in atmospheric particles. As mentioned in the Introduction, most of the previous laboratory work on liquid-liquid phase transitions of atmospheric importance have used $\left(\mathrm{NH}_{4}\right)_{2} \mathrm{SO}_{4}$ as the inorganic salt, even though sulfate is not always fully neutralized in atmospheric particles and $\mathrm{NO}_{3}^{-}$can make up a large fraction of the inorganic anions under certain conditions (Dibb et al., 1996; Huebert et al., 1998; Tolocka et al., 2005; Murphy et al., 2006; Zhang et al., 2007; Pratt and Prather, 2010). To address this disconnect, we have carried out liquid-liquid phase separation experiments with particles containing organics mixed with $\left(\mathrm{NH}_{4}\right)_{2} \mathrm{SO}_{4}, \mathrm{NH}_{4} \mathrm{HSO}_{4}$ and $\mathrm{NH}_{4} \mathrm{NO}_{3}$. The results from these studies show that in all cases, liquid-liquid phase separation is a common occurrence when $\mathrm{O}: \mathrm{C}<0.8$ and always observed when $\mathrm{O}: \mathrm{C}$ $<0.5$. These ranges of $\mathrm{O}: \mathrm{C}$ values are frequently observed in the atmosphere, suggesting that liquid-liquid phase separation is a common process in atmospheric particles, regardless of the identity of the salt.

In the marine boundary layer, supermicron particles containing $\mathrm{NaCl}$ make up a large fraction of the particulate mass (Quinn and Bates, 2005; Seinfeld and Pandis, 2006). These particles, which are produced from a bubble bursting mechanism (Woodcock et al., 1953; Blanchard and Woodcock, 1957), can often contain relatively low O:C organics such as sterols, fatty acids and fatty alcohols (Schneider and Gagosian, 1985; Peltzer and Gagosian, 1987; Sicre et al., 1990; Kawamura et al., 2003). Based on the liquid-liquid phase separation results for $\mathrm{NaCl}$ containing particles presented here and the $\mathrm{O}: \mathrm{C}$ of sterols, fatty acids and fatty alcohols (O:C less than approximately 0.5$)$ thought to be present in the marine boundary layer, liquid-liquid phase separation is also expected to be a common occurrence in marine environments.

\section{Conclusions}

Out of 92 types of particles studied, 49 underwent liquidliquid phase separation. For all the inorganic salts, liquidliquid phase separation was never observed when $\mathrm{O}: \mathrm{C} \geq$ 0.8 and was always observed for $\mathrm{O}: \mathrm{C}<0.5$. For $0.5 \leq \mathrm{O}: \overline{\mathrm{C}}$ $<0.8$, the results depended on the salt type. In addition, a correlation between the separation relative humidity (SRH) and $\mathrm{O}: \mathrm{C}$ was observed for all inorganic salts, suggesting that $\mathrm{O}: \mathrm{C}$ is a useful parameter for estimating, to a first approximation, the relative humidity for liquid-liquid phase separation, although additional information will be required for predictions with high accuracy.

Out of the 23 organics investigated, the SRH of 20 organics had the following trend: $\left(\mathrm{NH}_{4}\right)_{2} \mathrm{SO}_{4} \geq \mathrm{NH}_{4} \mathrm{HSO}_{4} \geq$ $\mathrm{NaCl} \geq \mathrm{NH}_{4} \mathrm{NO}_{3}$. The trend is consistent with previous salting out studies and the Hofmeister series. Based on the range of $\mathrm{O}: \mathrm{C}$ values found in the atmosphere and the current results, liquid-liquid phase separation is likely a common occurrence in marine and non-marine environments.

\section{Supplementary material related to this article is available online at http://www.atmos-chem-phys.net/13/ 11723/2013/acp-13-11723-2013-supplement.zip.}


Table 4. Summary of SRH results as a function of the organic-to-inorganic (OIR) mass ratio for following organics: 2,2-dimethylsuccinic acid; $\alpha$,4-dihydroxy-3-methoxybenzeneacetic acid; and 2,5-dihydroxybenzonic acid. Included are results from both the current studies and results from Bertram et al. (2011). Uncertainties represent $2 \sigma$ of multiple SRH measurements and the uncertainty from the calibration.

\begin{tabular}{|c|c|c|c|c|c|c|c|c|}
\hline \multirow[t]{2}{*}{ Organics } & \multicolumn{2}{|c|}{$\left(\mathrm{NH}_{4}\right)_{2} \mathrm{SO}_{4}$} & \multicolumn{2}{|c|}{$\mathrm{NH}_{4} \mathrm{HSO}_{4}$} & \multicolumn{2}{|c|}{$\mathrm{NaCl}$} & \multicolumn{2}{|c|}{$\mathrm{NH}_{4} \mathrm{NO}_{3}$} \\
\hline & OIR & $\mathrm{SRH}(\%)$ & OIR & $\mathrm{SRH}(\%)$ & OIR & $\mathrm{SRH}(\%)$ & OIR & SRH $(\%)$ \\
\hline 2,2-dimethylsuccinic acid & $\begin{array}{l}2.0^{\mathrm{b}} \\
0.3^{\mathrm{b}} \\
0.5^{\mathrm{b}} \\
1.0^{\mathrm{b}} \\
1.2^{\mathrm{b}} \\
1.5^{\mathrm{b}}\end{array}$ & $\begin{array}{c}\text { Not observed }^{\mathrm{a}} \\
63.8 \pm 2.5^{\mathrm{b}} \\
61.5 \pm 2.5^{\mathrm{b}} \\
\text { Not observed }^{\mathrm{b}} \\
\text { Not observed }^{\mathrm{b}} \\
\text { Not observed }^{\mathrm{b}}\end{array}$ & $\begin{array}{l}2.0 \\
0.5\end{array}$ & $\begin{array}{l}61.4 \pm 2.5 \\
61.2 \pm 2.5\end{array}$ & $\begin{array}{l}2.1 \\
0.5\end{array}$ & $\begin{array}{l}58.9 \pm 2.6 \\
60.0 \pm 3.1\end{array}$ & $\begin{array}{l}1.9 \\
0.5\end{array}$ & $\begin{array}{l}40.0 \pm 3.2 \\
41.4 \pm 2.7\end{array}$ \\
\hline$\alpha, 4$-dihydroxy-3-methoxybenzeneacetic acid & $\begin{array}{l}2.0^{0} \\
0.4^{\mathrm{b}} \\
1.0^{\mathrm{b}} \\
6.0^{\mathrm{b}}\end{array}$ & $\begin{array}{c}72.6 \pm 2.6 \\
80.1 \pm 2.5^{\mathrm{b}} \\
81.3 \pm 2.5^{\mathrm{b}} \\
\text { Not observed }^{\mathrm{b}}\end{array}$ & $\begin{array}{l}2.0 \\
0.5\end{array}$ & $\begin{array}{l}38.2 \pm 2.7 \\
46.3 \pm 3.0\end{array}$ & $\begin{array}{l}1.9 \\
0.5\end{array}$ & $\begin{array}{l}63.1 \pm 2.9 \\
62.6 \pm 2.6\end{array}$ & $\begin{array}{l}1.9 \\
0.5\end{array}$ & $\begin{array}{l}\text { Not observed } \\
\text { Not observed }\end{array}$ \\
\hline 2,5-dihydroxybenzoic acid & $\begin{array}{l}2.0^{2} \\
0.2^{\mathrm{b}} \\
0.3^{\mathrm{b}} \\
0.5^{\mathrm{b}} \\
0.8^{\mathrm{b}} \\
1.0^{\mathrm{b}} \\
1.5^{\mathrm{b}}\end{array}$ & $\begin{array}{c}\text { Not observed } \\
61.6 \pm 2.5^{b} \\
64.2 \pm 2.5^{b} \\
62.9 \pm 2.5^{b} \\
\text { Not observed }^{b} \\
\text { Not observed } \\
\text { Not observed }\end{array}$ & $\begin{array}{l}1.9 \\
0.5\end{array}$ & $\begin{array}{l}\text { Not observed } \\
\text { Not observed }\end{array}$ & $\begin{array}{l}2.0 \\
0.5\end{array}$ & $\begin{array}{l}65.5 \pm 3.1 \\
65.2 \pm 2.6\end{array}$ & $\begin{array}{l}2.0 \\
0.5\end{array}$ & $\begin{array}{l}\text { Not observed } \\
\text { Not observed }\end{array}$ \\
\hline
\end{tabular}

a Not observed means liquid-liquid phase separation was not observed for the range of relative humidities probed. In some cases SRH was not probed below $20-40 \%$ RH since at RH values less than these values efflorescence of the inorganic salt occurred. ${ }^{b}$ Data from previous study of Bertram et al. (2011).

Acknowledgements. This research was supported by the Natural Sciences and Engineering Research Council of Canada. The authors thank M. Petters for helpful discussions on the Hofmeister series.

Edited by: T. Koop

\section{References}

Abbatt, J. P. D., Benz, S., Cziczo, D. J., Kanji, Z., Lohmann, U., and Möhler, O.: Solid ammonium sulfate aerosols as ice nuclei: A pathway for cirrus cloud formation, Science, 313, 1770-1773, doi:10.1126/science.1129726, 2006.

Adams, P. J., Seinfeld, J. H., and Koch, D. M.: Global concentrations of tropospheric sulfate, nitrate, and ammonium aerosol simulated in a general circulation model, J. Geophys. Res.-Atmos., 104, 13791-13823, doi:10.1029/1999jd900083, 1999.

Adams, P. J., Seinfeld, J. H., Koch, D., Mickley, L., and Jacob, D.: General circulation model assessment of direct radiative forcing by the sulfate-nitrate-ammonium-water inorganic aerosol system, J. Geophys. Res.-Atmos., 106, 1097-1111, doi:10.1029/2000JD900512, 2001.

Aiken, A. C., Decarlo, P. F., Kroll, J. H., Worsnop, D. R., Huffman, J. A., Docherty, K. S., Ulbrich, I. M., Mohr, C., Kimmel, J. R., Sueper, D., Sun, Y., Zhang, Q., Trimborn, A., Northway, M., Ziemann, P. J., Canagaratna, M. R., Onasch, T. B., Alfarra, M. R., Prevot, A. S. H., Dommen, J., Duplissy, J., Metzger, A., Baltensperger, U., and Jimenez, J. L.: O/C and OM/OC ratios of primary, secondary, and ambient organic aerosols with high- resolution time-of-flight aerosol mass spectrometry, Environ. Sci. Technol., 42, 4478-4485, doi:10.1021/es703009q, 2008.

Anttila, T., Kiendler-Scharr, A., Tillmann, R., and Mentel, T. F.: On the reactive uptake of gaseous compounds by organic-coated aqueous aerosols: Theoretical analysis and application to the heterogeneous hydrolysis of $\mathrm{N}_{2} \mathrm{O}_{5}$, J. Phys. Chem. A, 110, doi:10.1021/jp062403c 10435-10443, 2006.

Anttila, T., Kiendler-Scharr, A., Mentel, T. F., and Tillmann, R.: Size dependent partitioning of organic material: evidence for the formation of organic coatings on aqueous aerosols, J. Atmos. Chem., 57, 215-237, doi:10.1007/s10874-007-9067-9, 2007.

Badger, C. L., George, I., Griffiths, P. T., Braban, C. F., Cox, R. A., and Abbatt, J. P. D.: Phase transitions and hygroscopic growth of aerosol particles containing humic acid and mixtures of humic acid and ammonium sulphate, Atmos. Chem. Phys., 6, 755-768, doi:10.5194/acp-6-755-2006, 2006.

Bertram, A. K., Martin, S. T., Hanna, S. J., Smith, M. L., Bodsworth, A., Chen, Q., Kuwata, M., Liu, A., You, Y., and Zorn, S. R.: Predicting the relative humidities of liquid-liquid phase separation, efflorescence, and deliquescence of mixed particles of ammonium sulfate, organic material, and water using the organic-to-sulfate mass ratio of the particle and the oxygen-tocarbon elemental ratio of the organic component, Atmos. Chem. Phys., 11, 10995-11006, doi:10.5194/acp-11-10995-2011, 2011.

Blanchard, D. C. and Woodcock, A. H.: Bubble formation and modification in the sea and its meteorological significance, Tellus, 9, 145-158, doi:10.1111/j.2153-3490.1957.tb01867.x, 1957.

Bodsworth, A., Zobrist, B., and Bertram, A. K.: Inhibition of efflorescence in mixed organic-inorganic particles at temperatures 
less than $250 \mathrm{~K}$, Phys. Chem. Chem. Phys., 12, 12259-12266, doi:10.1039/c0cp00572j, 2010.

Braban, C. F. and Abbatt, J. P. D.: A study of the phase transition behavior of mixed ammonium sulfate - malonic acid aerosols, Atmos. Chem. Phys., 4, 1451-1459, doi:10.5194/acpd-4-29492004, 2004.

Brooks, S. D., Wise, M. E., Cushing, M., and Tolbert, M. A.: Deliquescence behavior of organic/ammonium sulfate aerosol, Geophys. Res. Lett., 29, 1917, doi:10.1029/2002GL014733, 2002.

Brooks, S. D., Garland, R. M., Wise, M. E., Prenni, A. J., Cushing, M., Hewitt, E., and Tolbert, M. A.: Phase changes in internally mixed maleic acid/ammonium sulfate aerosols, J. Geophys. Res.Atmos., 108, 4478, doi:10.1029/2002jd003204, 2003.

Buajarern, J., Mitchem, L., and Reid, J. P.: Characterizing multiphase organic/inorganic/aqueous aerosol droplets, J. Phys. Chem. A, 111, 9054-9061, doi:10.1021/jp074366a, 2007a.

Buajarern, J., Mitchem, L., and Reid, J. P.: Characterizing the formation of organic layers on the surface of inorganic/aqueous aerosols by Raman spectroscopy, J. Phys. Chem. A, 111, 1185211859, doi:10.1021/Jp075021v, 2007b.

Chan, M. N. and Chan, C. K.: Hygroscopic properties of two model humic-like substances and their mixtures with inorganics of atmospheric importance, Environ. Sci. Technol., 37, 5109-5115, doi:10.1021/es034272o, 2003.

Chang, E. I. and Pankow, J. F.: Prediction of activity coefficients in liquid aerosol particles containing organic compounds, dissolved inorganic salts, and water - Part. 2: Consideration of phase separation effects by an X-UNIFAC model, Atmos. Environ., 40, 6422-6436, doi:10.1016/j.atmosenv.2006.04.031, 2006.

Chen, Q., Farmer, D. K., Schneider, J., Zorn, S. R., Heald, C. L., Karl, T. G., Guenther, A., Allan, J. D., Robinson, N., Coe, H., Kimmel, J. R., Pauliquevis, T., Borrmann, S., Pöschl, U., Andreae, M. O., Artaxo, P., Jimenez, J. L., and Martin, S. T.: Mass spectral characterization of submicron biogenic organic particles in the Amazon Basin, Geophys. Res. Lett., 36, L20806, doi:10.1029/2009GL039880, 2009.

Choi, M. Y. and Chan, C. K.: The effects of organic species on the hygroscopic behaviors of inorganic aerosols, Environ. Sci. Technol., 36, 2422-2428, doi:10.1021/es0113293, 2002.

Ciobanu, V. G., Marcolli, C., Krieger, U. K., Weers, U., and Peter, T.: Liquid-liquid phase separation in mixed organic/inorganic aerosol particles, J. Phys. Chem. A, 113, 10966-10978, doi:10.1021/jp905054d, 2009.

Clegg, S. L., Seinfeld, J. H., and Brimblecombe, P.: Thermodynamic modelling of aqueous aerosols containing electrolytes and dissolved organic compounds, J. Aerosol. Sci., 32, 713-738, doi:10.1016/S0021-8502(00)00105-1, 2001.

Day, D. A., Takahama, S., Gilardoni, S., and Russell, L. M.: Organic composition of single and submicron particles in different regions of western North America and the eastern Pacific during INTEX-B 2006, Atmos. Chem. Phys., 9, 5433-5446, doi:10.5194/acp-9-5433-2009, 2009.

DeCarlo, P. F., Dunlea, E. J., Kimmel, J. R., Aiken, A. C., Sueper, D., Crounse, J., Wennberg, P. O., Emmons, L., Shinozuka, Y., Clarke, A., Zhou, J., Tomlinson, J., Collins, D. R., Knapp, D., Weinheimer, A. J., Montzka, D. D., Campos, T., and Jimenez, J. L.: Fast airborne aerosol size and chemistry measurements above Mexico City and Central Mexico during the MILAGRO cam- paign, Atmos. Chem. Phys., 8, 4027-4048, doi:10.5194/acp-84027-2008, 2008.

Decesari, S., Fuzzi, S., Facchini, M. C., Mircea, M., Emblico, L., Cavalli, F., Maenhaut, W., Chi, X., Schkolnik, G., Falkovich, A., Rudich, Y., Claeys, M., Pashynska, V., Vas, G., Kourtchev, I., Vermeylen, R., Hoffer, A., Andreae, M. O., Tagliavini, E., Moretti, F., and Artaxo, P.: Characterization of the organic composition of aerosols from Rondônia, Brazil, during the LBASMOCC 2002 experiment and its representation through model compounds, Atmos. Chem. Phys., 6, 375-402, doi:10.5194/acp6-375-2006, 2006.

Dibb, J. E., Talbot, R. W., Klemm, K. I., Gregory, G. L., Singh, H. B., Bradshaw, J. D., and Sandholm, S. T.: Asian influence over the western North Pacific during the fall season: Inferences from lead 210, soluble ionic species and ozone, J. Geophys. Res.Atmos., 101, 1779-1792, doi:10.1029/94JD03117, 1996.

Erdakos, G. B. and Pankow, J. F.: Gas/particle partitioning of neutral and ionizing compounds to single- and multi-phase aerosol particles. 2. Phase separation in liquid particulate matter containing both polar and low-polarity organic compounds, Atmos. Environ., 38, 1005-1013, doi:10.1016/j.atmosenv.2003.10.038, 2004.

Erdakos, G. B., Asher, W. E., Seinfeld, J. H., and Pankow, J. F.: Prediction of activity coefficients in liquid aerosol particles containing organic compounds, dissolved inorganic salts, and water Part. 1: Organic compounds and water by consideration of shortand long-range effects using X-UNIFAC.1, Atmos. Environ., 40, 6410-6421, doi:10.1016/j.atmosenv.2006.04.030, 2006a.

Erdakos, G. B., Chang, E. I., Pankow, J. F., and Seinfeld, J. H.: Prediction of activity coefficients in liquid aerosol particles containing organic compounds, dissolved inorganic salts, and water - Part. 3: Organic compounds, water, and ionic constituents by consideration of short-, mid-, and long-range effects using X-UNIFAC.3, Atmos. Environ., 40, 6437-6452, doi:10.1016/j.atmosenv.2006.04.001, 2006b.

Escoreia, E. N., Sjostedt, S. J., and Abbatt, J. P. D.: Kinetics of $\mathrm{N}_{2} \mathrm{O}_{5}$ hydrolysis on secondary organic aerosol and mixed ammonium bisulfate-secondary organic aerosol particles, J. Phys Chem. A, 114, 13113-13121, doi:10.1021/jp107721v, 2010.

Finlayson-Pitts, B. J. and Pitts, J. N.: Tropospheric air pollution, Ozone, airborne toxics, polycyclic aromatic hydrocarbons, and particles, Science, 276, 1045-1052, doi:10.1126/science.276.5315.1045, 1997.

Finlayson-Pitts, B. J. and Pitts, J. N.: Chemistry of the upper and lower atmosphere, theory, experiments and applications, Academic Press, San Diego, Calif., London, xxii, 969 pp., 2000.

Folkers, M., Mentel, T. F., and Wahner, A.: Influence of an organic coating on the reactivity of aqueous aerosols probed by the heterogeneous hydrolysis of $\mathrm{N}_{2} \mathrm{O}_{5}$, Geophys. Res. Lett., 30, 1644, doi:10.1029/2003GL017168, 2003.

Fu, P. Q., Kawamura, K., and Miura, K.: Molecular characterization of marine organic aerosols collected during a roundthe-world cruise, J. Geophys. Res.-Atmos., 116, D13302, doi:10.1029/2011jd015604, 2011.

Gilardoni, S., Liu, S., Takahama, S., Russell, L. M., Allan, J. D., Steinbrecher, R., Jimenez, J. L., De Carlo, P. F., Dunlea, E. J., and Baumgardner, D.: Characterization of organic ambient aerosol during MIRAGE 2006 on three platforms, Atmos. Chem. Phys., 9, 5417-5432, doi:10.5194/acp-9-5417-2009, 2009. 
Goldstein, A. H. and Galbally, I. E.: Known and unexplored organic constituents in the earth's atmosphere, Environ. Sci. Technol., 41, 1514-1521, doi:10.1021/es072476p, 2007.

Hallquist, M., Wenger, J. C., Baltensperger, U., Rudich, Y., Simpson, D., Claeys, M., Dommen, J., Donahue, N. M., George, C., Goldstein, A. H., Hamilton, J. F., Herrmann, H., Hoffmann, T., Iinuma, Y., Jang, M., Jenkin, M. E., Jimenez, J. L., Kiendler-Scharr, A., Maenhaut, W., McFiggans, G., Mentel, Th. F., Monod, A., Prévôt, A. S. H., Seinfeld, J. H., Surratt, J. D., Szmigielski, R., and Wildt, J.: The formation, properties and impact of secondary organic aerosol: current and emerging issues, Atmos. Chem. Phys., 9, 5155-5236, doi:10.5194/acp-9-51552009, 2009.

Hamilton, J. F., Webb, P. J., Lewis, A. C., Hopkins, J. R., Smith, S., and Davy, P.: Partially oxidised organic components in urban aerosol using GCXGC-TOF/MS, Atmos. Chem. Phys., 4, 12791290, doi:10.5194/acp-4-1279-2004, 2004.

Hawkins, L. N., Russell, L. M., Covert, D. S., Quinn, P. K., and Bates, T. S.: Carboxylic acids, sulfates, and organosulfates in processed continental organic aerosol over the southeast Pacific Ocean during VOCALS-REx 2008, J. Geophys. Res.-Atmos., 115, D13201, doi:10.1029/2009jd013276, 2010.

Heald, C. L., Kroll, J. H., Jimenez, J. L., Docherty, K. S., DeCarlo, P. F., Aiken, A. C., Chen, Q., Martin, S. T., Farmer, D. K., and Artaxo, P.: A simplified description of the evolution of organic aerosol composition in the atmosphere, Geophys. Res. Lett., 37, L08803, doi:10.1029/2010g1042737, 2010.

Hofmeister, F.: Zur lehre von der wirkung der salze, Arch. Exp. Pathol. Phar., 24, 247-260, 1887.

Hofmeister, F.: Zur lehre von der wirkung der salze, Arch. Exp. Pathol. Phar., 25, 1-30, 1888.

Huebert, B. J., Howell, S. G., Zhuang, L., Heath, J. A., Litchy, M. R., Wylie, D. J., Kreidler-Moss, J. L., Cöppicus, S., and Pfeiffer, J. E.: Filter and impactor measurements of anions and cations during the First Aerosol Characterization Experiment (ACE 1), J. Geophys. Res.-Atmos., 103, 16493-16509, doi:10.1029/98jd00770, 1998.

Forster, P., Ramaswamy, V., Artaxo, P., Berntsen, T., Betts, R., Fahey, D. W., Haywood, J., Lean, J., Lowe, D. C., Myhre, G., Nganga, J., Prinn, R., Raga, G., Schulz, M., and Van Dorland, R.: Changes in Atmospheric Constitutents and in Radiative Forcing, in: Climate Change 2007: The Physical Science Basis. Contribution of working Group I to the Fourth Assessment Report of the Intergovernmental Panel on Climate Changes. Edited by: Solomon, S., Qin, D., Manning, M., Chen, Z., Marquis,M., Averyt, K. B., Tignor, M., and Miller, H. L., 2007, Cambridge University Press, Cambridge, United Kindom and New York, NY, USA.

Jimenez, J. L., Canagaratna, M. R., Donahue, N. M., Prevot, A. S. H., Zhang, Q., Kroll, J. H., DeCarlo, P. F., Allan, J. D., Coe, H., Ng, N. L., Aiken, A. C., Docherty, K. S., Ulbrich, I. M., Grieshop, A. P., Robinson, A. L., Duplissy, J., Smith, J. D., Wilson, K. R., Lanz, V. A., Hueglin, C., Sun, Y. L., Tian, J., Laaksonen, A., Raatikainen, T., Rautiainen, J., Vaattovaara, P., Ehn, M., Kulmala, M., Tomlinson, J. M., Collins, D. R., Cubison, M. J., Dunlea, E. J., Huffman, J. A., Onasch, T. B., Alfarra, M. R., Williams, P. I., Bower, K., Kondo, Y., Schneider, J., Drewnick, F., Borrmann, S., Weimer, S., Demerjian, K., Salcedo, D., Cottrell, L., Griffin, R., Takami, A., Miyoshi, T.,
Hatakeyama, S., Shimono, A., Sun, J. Y., Zhang, Y. M., Dzepina, K., Kimmel, J. R., Sueper, D., Jayne, J. T., Herndon, S. C., Trimborn, A. M., Williams, L. R., Wood, E. C., Middlebrook, A. M., Kolb, C. E., Baltensperger, U., and Worsnop, D. R.: Evolution of organic aerosols in the atmosphere, Science, 326, 1525-1529, doi:10.1126/science.1180353, 2009.

Kawamura, K., Ishimura, Y., and Yamazaki, K.: Four years' observations of terrestrial lipid class compounds in marine aerosols from the western North Pacific, Global. Biogeochem. Cy., 17, 1003, doi:10.1029/2001gb001810, 2003.

Koop, T., Kapilashrami, A., Molina, L. T., and Molina, M. J.: Phase transitions of sea-salt/water mixtures at low temperatures: Implications for ozone chemistry in the polar marine boundary layer, J. Geophys. Res.-Atmos., 105, 26393-26402, doi:10.1029/2000JD900413, 2000.

Kumpf, R. A. and Dougherty, D. A.: A mechanism for ion selectivity in potassium channels Computational studies of cation- $\pi$ interactions, Science, 261, 1708-1710, doi:10.1126/science.8378771, 1993.

Kunz, W., Henle, J., and Ninham, B. W.: "Zur Lehre von der Wirkung der Salze" (about the science of the effect of salts): Franz Hofmeister's historical papers, Curr. Opin. Colloid. In., 9, 19-37, doi:10.1016/j.cocis.2004.05.005, 2004.

Kwamena, N. O. A., Buajarern, J., and Reid, J. P.: Equilibrium morphology of mixed organic/inorganic/aqueous aerosol droplets: investigating the effect of relative humidity and surfactants, J. Phys. Chem. A, 114, 5787-5795, doi:10.1021/jp1003648, 2010.

Laskin, A., Moffet, R. C., Gilles, M. K., Fast, J. D., Zaveri, R. A., Wang, B. B., Nigge, P., and Shutthanandan, J.: Tropospheric chemistry of internally mixed sea salt and organic particles: Surprising reactivity of $\mathrm{NaCl}$ with weak organic acids, J. Geophys. Res.-Atmos., 117, D15302, doi:10.1029/2012JD017743, 2012.

Lee, Y.-N., Weber, R., Ma, Y., Orsini, D., Maxwell-Meier, K., Blake, D., Meinardi, S., Sachse, G., Harward, C., Chen, T.-Y., Thornton, D., Tu, F.-H., and Bandy, A.: Airborne measurement of inorganic ionic components of fine aerosol particles using the particle-into-liquid sampler coupled to ion chromatography technique during ACE-Asia and TRACE-P, J. Geophys. Res.-Atmos., 108, 8646, doi:10.1029/2002JD003265, 2003.

Ling, T. Y. and Chan, C. K.: Partical crystallization and deliquescence of particles containing ammonium sulfate and dicarboxylic acids, J. Geophys. Res.-Atmos., 113, D14205, doi:10.1029/2008JD009779, 2008.

Liu, S., Takahama, S., Russell, L. M., Gilardoni, S., and Baumgardner, D.: Oxygenated organic functional groups and their sources in single and submicron organic particles in MILAGRO 2006 campaign, Atmos. Chem. Phys., 9, 6849-6863, doi:10.5194/acp9-6849-2009, 2009.

Ma, J. C. and Dougherty, D. A.: The cation- $\pi$ interaction, Chem. Rev., 97, 1303-1324, doi:10.1021/cr9603744, 1997.

Marcolli, C. and Krieger, U. K.: Phase changes during hygroscopic cycles of mixed organic/inorganic model systems of tropospheric aerosols, J. Phys. Chem. A, 110, 1881-1893, doi:10.1021/jp0556759, 2006.

Martin, S. T.: Phase transitions of aqueous atmospheric particles, Chem. Rev., 100, 3403-3453, doi:10.1021/cr990034t, 2000.

Martin, S. T., Hung, H.-M., Park, R. J., Jacob, D. J., Spurr, R. J. D., Chance, K. V., and Chin, M.: Effects of the physical state of tropospheric ammonium-sulfate-nitrate particles on global 
aerosol direct radiative forcing, Atmos. Chem. Phys., 4, 183214, doi:10.5194/acp-4-183-2004, 2004.

Murphy, D. M., Thomson, D. S., and Mahoney, T. M. J.: In situ measurements of organics, meteoritic material, mercury, and other elements in aerosols at 5 to 19 kilometers, Science, 282, 16641669, doi:10.1126/science.282.5394.1664, 1998.

Murphy, D. M., Cziczo, D. J., Froyd, K. D., Hudson, P. K., Matthew, B. M., Middlebrook, A. M., Peltier, R. E., Sullivan, A., Thomson, D. S., and Weber, R. J.: Single-particle mass spectrometry of tropospheric aerosol particles, J. Geophys. Res.-Atmos., 111, D23S32, doi:10.1029/2006JD007340, 2006.

Ng, N. L., Canagaratna, M. R., Zhang, Q., Jimenez, J. L., Tian, J., Ulbrich, I. M., Kroll, J. H., Docherty, K. S., Chhabra, P. S., Bahreini, R., Murphy, S. M., Seinfeld, J. H., Hildebrandt, L., Donahue, N. M., DeCarlo, P. F., Lanz, V. A., Prévôt, A. S. H., Dinar, E., Rudich, Y., and Worsnop, D. R.: Organic aerosol components observed in Northern Hemispheric datasets from Aerosol Mass Spectrometry, Atmos. Chem. Phys., 10, 46254641, doi:10.5194/acp-10-4625-2010, 2010.

Pankow, J. F.: Gas/particle partitioning of neutral and ionizing compounds to single and multi-phase aerosol particles. 1. Unified modeling framework, Atmos. Environ., 37, 3323-3333, doi:10.1016/S1352-2310(03)00346-7, 2003.

Pant, A., Fok, A., Parsons, M. T., Mak, J., and Bertram, A. K.: Deliquescence and crystallization of ammonium sulfate-glutaric acid and sodium chloride-glutaric acid particles, Geophys. Res. Lett., 31, L12111, doi:10.1029/2004GL020025, 2004.

Pant, A., Parsons, M. T., and Bertram, A. K.: Crystallization of aqueous ammonium sulfate particles internally mixed with soot and kaolinite: Crystallization relative humidities and nucleation rates, J. Phys. Chem. A, 110, 8701-8709, doi:10.1021/jp060985s, 2006.

Parsons, M. T., Knopf, D. A., and Bertram, A. K.: Deliquescence and crystallization of ammonium sulfate particles internally mixed with water-soluble organic compounds, J. Phys. Chem. A, 108, 11600-11608, doi:10.1021/jp0462862, 2004a.

Parsons, M. T., Mak, J., Lipetz, S. R., and Bertram, A. K.: Deliquescence of malonic, succinic, glutaric, and adipic acid particles, J. Geophys. Res.-Atmos., 109, D06212, doi:10.1029/2003JD004075, 2004b.

Parsons, M. T., Riffell, J. L., and Bertram, A. K.: Crystallization of aqueous inorganic-malonic acid particles: Nucleation rates, dependence on size, and dependence on the ammonium-to-sulfate, J. Phys. Chem. A, 110, 8108-8115, doi:10.1021/jp057074n, 2006.

Peltzer, E. T. and Gagosian, R. B.: Sampling and quantitation of lipids in aerosols from the remote marine atmosphere, Anal. Chim. Acta, 198, 125-144, doi:10.1016/s0003-2670(00)850138, 1987.

Pratt, K. A. and Prather, K. A.: Aircraft measurements of vertical profiles of aerosol mixing states, J. Geophys. Res.-Atmos., 115, D11305, doi:10.1029/2009JD013150, 2010.

Prisle, N. L., Engelhart, G. J., Bilde, M., and Donahue, N. M.: Humidity influence on gas-particle phase partitioning of $\alpha$-pinene + $\mathrm{O}_{3}$ secondary organic aerosol, Geophys. Res. Lett., 37, L01802, doi:10.1029/2009GL041402, 2010.

Quinn, P. K. and Bates, T. S.: Regional aerosol properties, Comparisons of boundary layer measurements from ACE 1, ACE 2, aerosols99, INDOEX, ACE asia, TARFOX, and NEAQS, J. Geo- phys. Res.-Atmos., 110, D14202, doi:10.1029/2004jd004755, 2005.

Randall, M. and Failey, C. F.: The activity coefficient of nonelectrolytes in aqueous salt solutions from solubility measurements: The salting-out order of the ions, Chem. Rev., 4, 285-290, doi:10.1021/Cr60015a004, 1927.

Reid, J. P., Dennis-Smither, B. J., Kwamena, N. O. A., Miles, R. E. H., Hanford, K. L., and Homer, C. J.: The morphology of aerosol particles consisting of hydrophobic and hydrophilic phases, hydrocarbons. alcohols and fatty acids as the hydrophobic component, Phys. Chem. Chem. Phys., 13, 15559-15572, doi:10.1039/C1CP21510H, 2011.

Riemer, N., Vogel, H., Vogel, B., Anttila, T., Kiendler-Scharr, A., and Mentel, T. F.: Relative importance of organic coatings for the heterogeneous hydrolysis of $\mathrm{N}_{2} \mathrm{O}_{5}$ during summer in Europe, J. Geophys. Res.-Atmos., 114, D17307, doi:10.1029/2008JD011369, 2009.

Rogge, W. F., Mazurek, M. A., Hildemann, L. M., Cass, G. R., and Simoneit, B. R. T.: Quantification of urban organic aerosols at a molecular-level- dentification: Abundance and seasonalvariation, Atmos. Environ., 27, 1309-1330, doi:10.1016/09601686(93)90257-Y, 1993.

Russell, L. M., Takahama, S., Liu, S., Hawkins, L. N., Covert, D. S., Quinn, P. K., and Bates, T. S.: Oxygenated fraction and mass of organic aerosol from direct emission and atmospheric processing measured on the R/V Ronald Brown during TEXAQS/GoMACCS 2006, J. Geophys. Res.-Atmos., 114, D00F05, doi:10.1029/2008JD011275, 2009.

Russell, L. M., Bahadur, R., and Ziemann, P. J.: Identifying organic aerosol sources by comparing functional group composition in chamber and atmospheric particles, P. Natl. Acad. Sci. USA, 108, 3516-3521, doi:10.1073/pnas.1006461108, 2011.

Salcedo, D.: Equilibrium phase diagrams of aqueous mixtures of malonic acid and sulfate/ammonium salts, J. Phys. Chem. A, 110, 12158-12165, doi:10.1021/jp063850v, 2006.

Saxena, P. and Hildemann, L. M.: Water-soluble organics in atmospheric particles: A critical review of the literature and application of thermodynamics to identify candidate compounds, J. Atmos. Chem., 24, 57-109, doi:10.1007/BF00053823, 1996.

Schneider, J. K. and Gagosian, R. B.: Particle-size distribution of lipids in aerosols off the coast of Peru, J. Geophys. Res.-Atmos., 90, 7889-7898, doi:10.1029/JD090iD05p07889, 1985.

Seinfeld, J. H. and Pandis, S. N.: Atmospheric Chemistry and Physics: From Air pollution to Climate Change, 2nd ed., WileyInterscience, New Jersey, 2006.

Sicre, M.-A., Marty, J.-C., and Saliot, A.: n-alkanes, fatty-acid esters, and fatty-acid salts in size fractionated aerosols collected over the Mediterranean-Sea, J. Geophys. Res.-Atmos., 95, 36493657, doi:10.1029/JD095iD04p03649, 1990.

Smith, M. L., Kuwata, M., and Martin, S. T.: Secondary organic material produced by the dark ozonolysis of $\alpha$ pinene minimally affects the deliquescence and efflorescence of ammonium sulfate, Aerosol Sci. Technol., 45, 225-242, doi:10.1080/02786826.2010.532178, 2011.

Smith, M. L., Bertram, A. K., and Martin, S. T.: Deliquescence, efflorescence, and phase miscibility of mixed particles of ammonium sulfate and isoprene-derived secondary organic material, Atmos. Chem. Phys., 12, 9613-9628, doi:10.5194/acp-12-96132012, 2012. 
Smith, M. L., You, Y., Kuwata, M., Bertram, A. K., and Martin, S. T.: Phase transitions and phase miscibility of mixed particles of ammonium sulfate, toluene-derived secondary organic material, and water, J. Phys. Chem. A, 117, 8895-8906, doi:10.1021/jp405095e, 2013.

Song, M., Marcolli, C., Krieger, U. K., Zuend, A., and Peter, T.: Liquid-liquid phase separation and morphology of internally mixed dicarboxylic acids/ammonium sulfate/water particles, Atmos. Chem. Phys., 12, 2691-2712, doi:10.5194/acp-12-26912012, 2012a.

Song, M., Marcolli, C., Krieger, U. K., Zuend, A., and Peter, T.: Liquid-liquid phase separation in aerosol particles: Dependence on $\mathrm{O}: \mathrm{C}$, organic functionalities, and compositional complexity, Geophys. Res. Lett., 39, L19801, doi:10.1029/2012GL052807, 2012b.

Takahama, S., Schwartz, R. E., Russell, L. M., Macdonald, A. M., Sharma, S., and Leaitch, W. R.: Organic functional groups in aerosol particles from burning and non-burning forest emissions at a high-elevation mountain site, Atmos. Chem. Phys., 11, 6367-6386, doi:10.5194/acp-11-6367-2011, 2011.

Thornton, J. A., Braban, C. F., and Abbatt, J. P. D.: $\mathrm{N}_{2} \mathrm{O}_{5}$ hydrolysis on sub-micron organic aerosols: the effect of relative humidity, particle phase, and particle size, Phys. Chem. Chem. Phys., 5, 4593-4603, doi:10.1039/B307498F, 2003.

Tolocka, M. P., Lake, D. A., Johnston, M. V., and Wexler, A. S.: Size-resolved fine and ultrafine particle composition in Baltimore, Maryland, J. Geophys. Res.-Atmos., 110, D07S04, doi:10.1029/2004JD004573, 2005.

Treuel, L., Pederzani, S., and Zellner, R.: Deliquescence behaviour and crystallisation of ternary ammonium sulfate/dicarboxylic acid/water aerosols, Phys. Chem. Chem. Phys., 11, 7976-7984, doi:10.1039/B905007H, 2009.

Wise, M. E., Surratt, J. D., Curtis, D. B., Shilling, J. E., and Tolbert, M. A.: Hygroscopic growth of ammonium sulfate/dicarboxylic acids, J. Geophys. Res.-Atmos., 108, 4638, doi:10.1029/2003JD003775, 2003.
Wise, M. E., Baustian, K. J., and Tolbert, M. A.: Internally mixed sulfate and organic particles as potential ice nuclei in the tropical tropopause region, P. Natl. Acad. Sci. USA, 107, 6693-6698, doi:10.1073/pnas.0913018107, 2010.

Woodcock, A. H., Kientzler, C. F., Arons, A. B., and Blanchard, D. C.: Giant condensation nuclei from bursting bubbles, Nature, 172, 1144-1145, doi:10.1038/1721144a0, 1953.

You, Y., Renbaum-Wolff, L., Carreras-Sospedra, M., Hanna, S. J., Hiranuma, N., Kamal, S., Smith, M. L., Zhang, X. L., Weber, R. J., Shilling, J. E., Dabdub, D., Martin, S. T., and Bertram, A. K.: Images reveal that atmospheric particles can undergo liquidliquid phase separations, P. Natl. Acad. Sci. USA, 109, 13188 13193, doi:10.1073/pnas.1206414109, 2012.

Zhang, Q., Jimenez, J. L., Canagaratna, M. R., Allan, J. D., Coe, H., Ulbrich, I., Alfarra, M. R., Takami, A., Middlebrook, A M., Sun, Y. L., Dzepina, K., Dunlea, E., Docherty, K., DeCarlo, P. F., Salcedo, D., Onasch, T., Jayne, J. T., Miyoshi, T., Shimono, A., Hatakeyama, S., Takegawa, N., Kondo, Y., Schneider, J., Drewnick, F., Borrmann, S., Weimer, S., Demerjian, K., Williams, P., Bower, K., Bahreini, R., Cottrell, L., Griffin, R. J., Rautiainen, J., Sun, J. Y., Zhang, Y. M., and Worsnop, D. R.: Ubiquity and dominance of oxygenated species in organic aerosols in anthropogenically-influenced Northern Hemisphere midlatitudes, Geophys. Res. Lett., 34, L13801, doi:10.1029/2007GL029979, 2007.

Zuberi, B., Bertram, A. K., Cassa, C. A., Molina, L. T., and Molina, M. J.: Heterogeneous nucleation of ice in $\left(\mathrm{NH}_{4}\right)_{2} \mathrm{SO}_{4}-\mathrm{H}_{2} \mathrm{O}$ particles with mineral dust immersions, Geophys. Res. Lett., 29, 1504, doi:10.1029/2001GL014289, 2002.

Zuend, A., Marcolli, C., Peter, T., and Seinfeld, J. H.: Computation of liquid-liquid equilibria and phase stabilities: implications for RH-dependent gas/particle partitioning of organic-inorganic aerosols, Atmos. Chem. Phys., 10, 7795-7820, doi:10.5194/acp10-7795-2010, 2010. 